\title{
Bien Dong seafloor spreading and its influence to formation \& development of sedimentary basins
}

- Hung Nguyen Manh

- Tien Hoang Dinh

University of Technology, VNU-HCM

\begin{abstract}
:
The paper presents the characteristics of Bien Dong seafloor spreading which including two parts: The Eastern part is quite large, in which developed by Eastern- Western orientation (spreading on N-S). The Southern- Western part gradually changed its orientation from $E-W$ into East- North and in to South- West at the end (spreading SE- NW).

There are two main dynamic resources created the spreading and deformation: The appearance of thermal abnormality by mantle plume occurred 36 M.a. until 14 M.a. The Eastern thermal anomalies continued to develop follow this orientation. In the SW-part the thermal anomalies changed it orientation from E-W into NE- SW 26 M.a and gradually developing toward S-W. Since

14 M.a, both two these trends been stopped, began to cooling and shrinkage. The abnormal existence caused pinchout and rifting the continental crust in Bien Dong Center and generating new oceanic crust as well. The uplift and variation of thermal abnormality (basalt magma) raised up the favorable conditions to forming, developing and varying the axis of Bien Dong spreading seafloor. The all above synthetic activities created favorable conditions for generation and development a series of deep fault systems with $E-W$ direction in Eastern part and NE- SW direction in Southern-Western direction in remain part, and created and evolved the sedimentary basins in margins of Bien Dong with along the main deep fault system.
\end{abstract}

Key words: Ben Dong seafloor spreading, thermal abnormality, favorable condition.

\section{CHARACTERISTICS OF BIEN DONG SEAFLOOR SPREADING}

Based on magnetic anomalies (fig. 1) the research region is separated in two parts such as: The Eastern part has E-W orientation, which includes magnetic anomalies as: 13, 11, 10, 9, 8, 7, 6b, 6a, 5e, 5d, 5c, 5a, from margin in to interior, corresponding ages: 36,32 , $30,29,28,26,24,20.5,19,18,17$ and 15.5 M.a (fig.2cross section A-Á)

In left hand-side at super area only is existed anomalies 13, 11 in upper and under and anomaly 10 in Central. While, in Eastern part these anomalies with younger anomalies (9, 8, 7 until 5a) are developed in two parts (upper and under) from anomaly $5 \mathrm{a}$ in Eastern part of Bien Dong Central area.

From anomaly 7 (26 M.a) S-W part of seafloor spreading changed orientation in beginning only $8-10$ degrees, after that increased to 38 degrees (24 M.a) and $40^{\circ}$ (19 M.a) until anomaly 5a (5.5 M.a) stopped. In this orientation the magnetic anomalies of seafloor spreading also has NE-SW orientation, from magnetic anomaly $6 \mathrm{~b}$ until anomaly $5 \mathrm{a}$ (cross section B-B). The more in SW only remained magnetic anomalies 5e until anomaly 5a, which developed forward SW (cross section C-C).

That mean, in Central area of Bien Dong Sea are existed 12 times of uplifts of basalt magma and erosion

\section{Trang B2}


of crust. The younger anomalies pushed up the old anomalies forward margins.

At the same time, the young anomalies developed in Central area and forward SW orientation (Fig.2 and 3). That mean, the magnetic anomalies 13 until 5a in Eastern part also kept the old E-W orientation, but these anomalies in S-W orientation changed into NE- SW due to extrusion toward S-E orientation of Indochinese block due to that these anomalies received the direct stress from Indochinese block (fig.03)

This figure is reflected by gravity anomalies (fig. 04, $05)$.

The Bien Dong seafloor spreading and deep main fault systems also are reflected in gravity charts (fig. 6).

Beside it, in gravity charts the seafloor spreading has three phases of intensive extensions perpendicular to extension axis (fig. 04). This extension appeared when the Indochinese block was extruded forward S-E orientation and wrenched in right in Middle of late Oligocene corresponding anomaly 7 (26 M.a), end of late Oligocene and beginning of early Miocene corresponding anomaly 6 (24 M.a), in end of Early Miocene corresponding anomaly 5a (15.5 M.a).

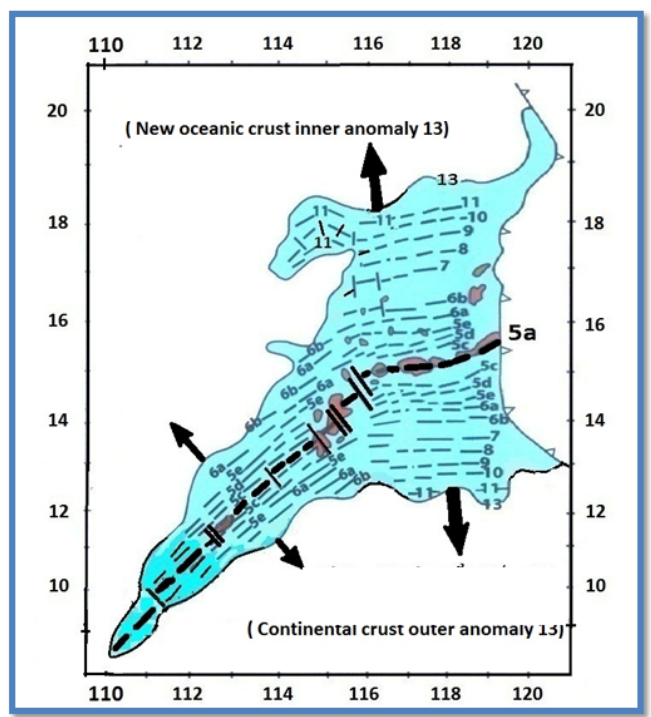

Figure 01: Magnetic anomalies in Center of Bien Dong

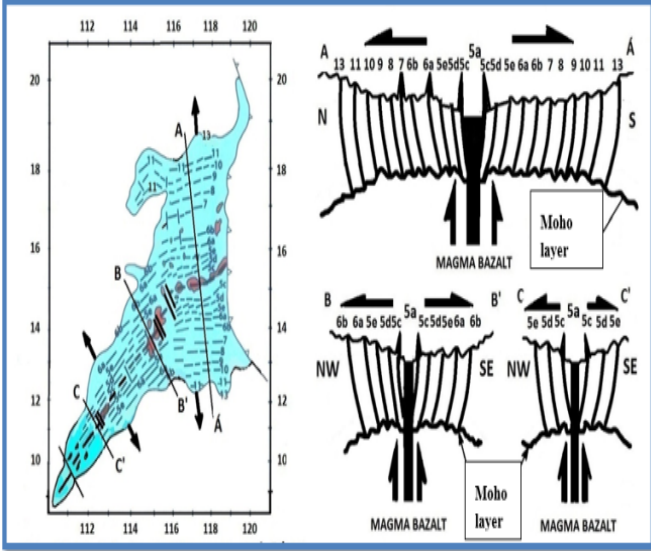

Figure 02a: Magnetic anomalies in Center of Bien
Dong $\begin{gathered}\text { Figure 02b: Cross section of magnetic } \\ \text { anomalies in Center of Bien Dong }\end{gathered}$

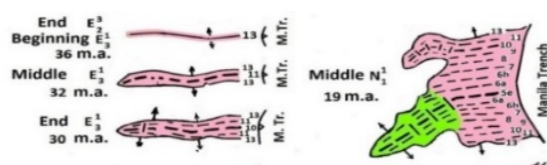

Beginning $E_{3}^{2}$
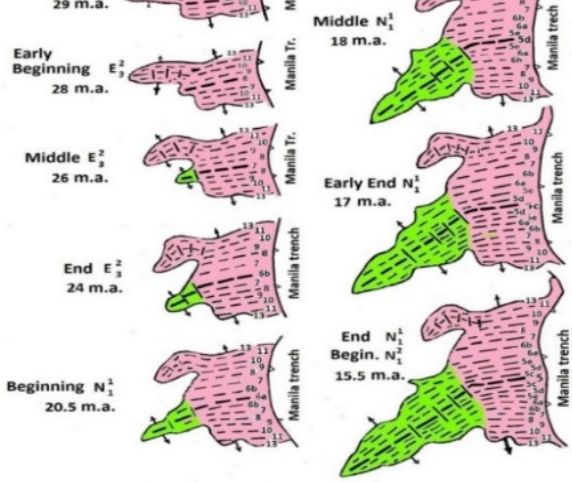

Fig. 3 The Evolution of Biển Đông Seafloor Spreading ( Reestablished by Hoàng Đình Tiến 2008 on base of magnetic Anomalies of Ben-Avraharm and Uyeda 1973

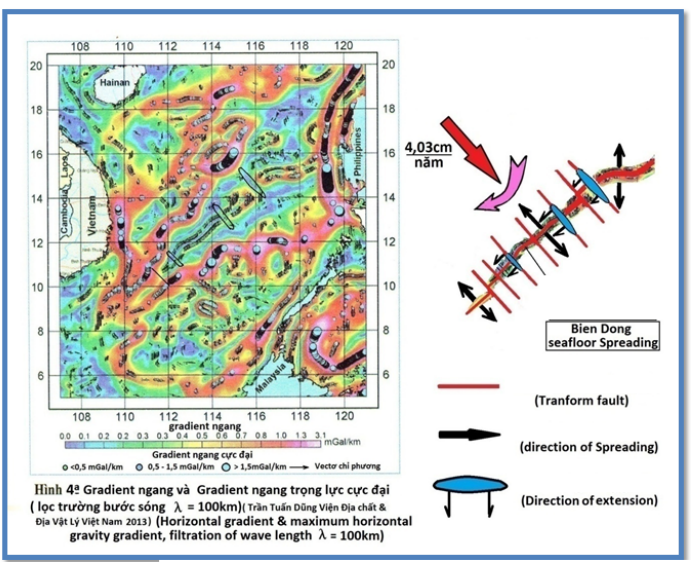

Figure 04a: Vertical and horizontal gradient of maximum gravity 


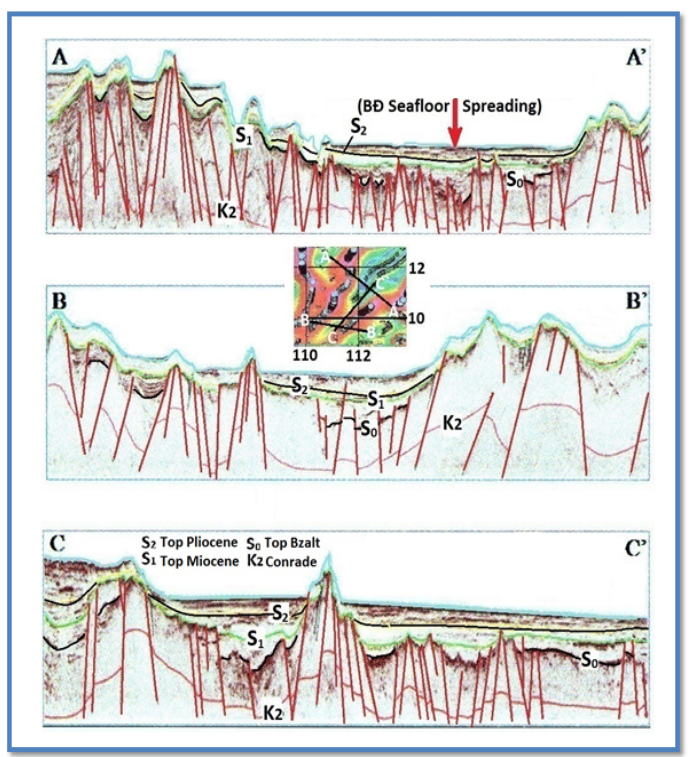

Figure 04b: Seismic cross section in SW part of Bien Dong sea (Dung Tran Tuan 2013)

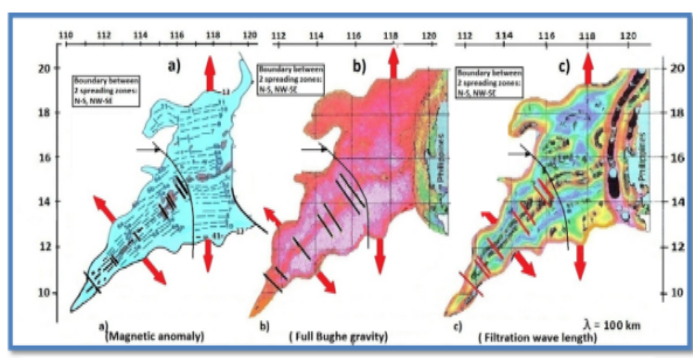

Figure 05: The magnetic abnormalities and full gravity, filtration of wave length $\lambda=100 \mathrm{~km}$.

\section{THE ENERGY RESOURCES OF BIEN DONG SEAFLOOR SPREADING}

a. The first energy resource of Bien Dong Seafloor spreading: in 1971, studying composition and nature of basalt magma, Flower M. and Nguyên Hoang noticed that the basalt magma only uplifted from mantle thermal plume (the thermal lingual has depth $\sim 25-30 \mathrm{~km}$ ). After that, Wanatabe et al. studied composition and nature of basalt and magnetic anomalies also noticed that existed the thermal anomaly to increase temperature in period from 36 M.a until 16 M.a, decreased the active intensity and after that until 14 M.a before absolutely stopped (fig.7).

The appearance of mantle thermal plume was raised and eroded the old continental crust in these areas and rifted. At the same time, the every rising uplift of basalt magma with thin crust at dome and thick crust in margins. These anomalies were cooled with the formation of new basalt magmatic layer and pushed up the old bazalt magmatic layer toward margins.

The nature of this process is the split and attenuation for the old continental crust, the open and development of the new oceanic crust in Central area of Bien Dong Sea. But this process of oceanic style only was existed in period from 36 M.a until 14 M.a.

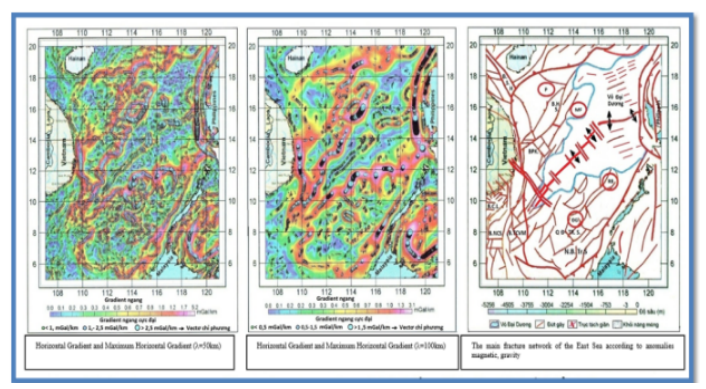

Figure 6: The relationship between gravity and main fault systems in BienDong sea.

After that, (from 14 M.a until now) the magmatic fluid was cooled, the continental crust was consolidated and gradually enlarged, thickened as present days.

Beside it, the basalt fragments, turbidite $(<$ $2000 \mathrm{~m}$ ), marine clay, some ophiolite fragments were discovered in S-E areas.

That mean, what factor the mantle thermal plume was raised from (?).

Studying the configuration of the mantle plume discovered that the thermal anomaly has belt form, which distributed cross the Indochinese block and was separated the small lingual in Bien Dong Sea, and was separated the thermal lingual in Eastern Philippine Sea. (fig. 07). The thermal lingual anomaly in Bien Dong Sea has the same long and narrow belt in E-W orientation, which raised up and formed Bien Dong seafloor spreading axis in this orientation. After that (only 26 M.a) S-W part of spreading axis gradually was changed into NE- SW. Due to this process the SW part of spreading axis also developed in NE- SW orientation until stop period (15.5 M.a).

Based on this cause the thermal anomaly was only formed due to subduction of oceanic crust IndoAustralia under continental crust Euro-Asia into depth

\section{Trang B4}


> 35- 40km. In this condition the oceanic crust IndoAustralia reached to the temperature of thousands ${ }^{\circ} \mathrm{C}$ and was burning- melting, dissolving one part of continental crust. In this condition the magmatic fluid was generated with increasing volume dissolving by gases and vapor, which speeded up the conversion in upper mantle and rising up ward to surface in Indochinese block, also in Bien Dong Sea. But in margins in contact of both crusts in subduction zone occurred the explosion along the volcanic arcs such as: Indonesia, Philippine.

If is established the cross section in 15 with Bien Dong seafloor Spreading (fig.8).

That mean, every time of rising of magmatic fluid, after that cooled and crystallized, remained the correspondent magnetic anomaly. These anomalies created the thicker crust of the oceanic crust (From 14 M.a until now). For that reason, Bien Dong Sea in general, Central part especially are located in passive zone, which belong to continental crust larged and crystallized, except for Manila subduction in Eastern margin (fig. 9).

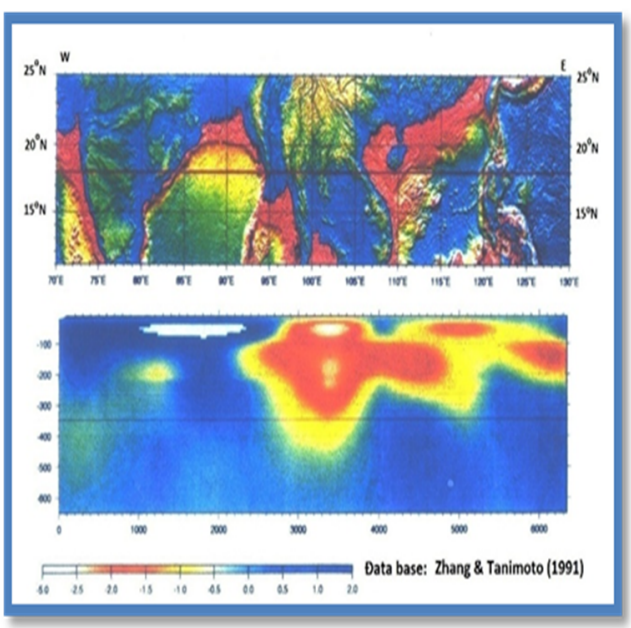

Figure 7: The thermal anomalities of Upper Mantle in SEA at $18 \mathrm{~N}$.

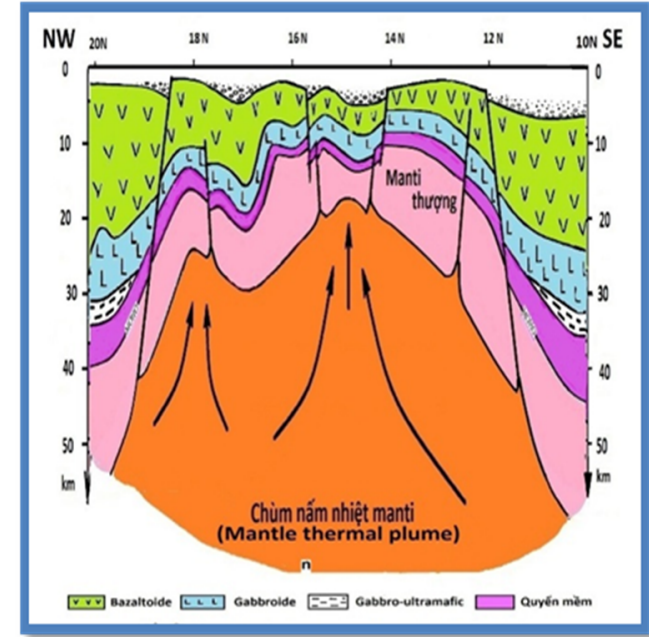

Figure 8: The cross section of Bien Dong sea center.

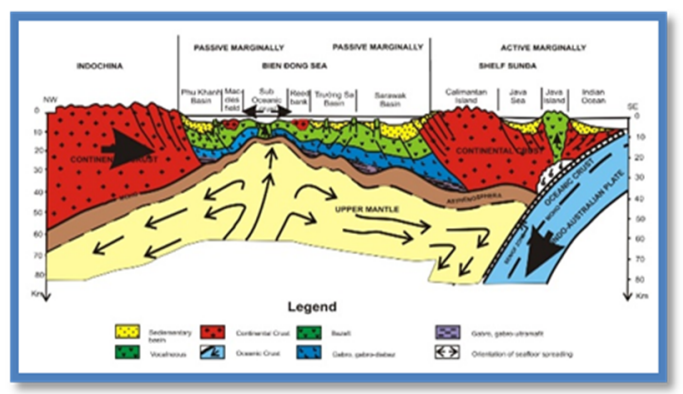

Figure 9: The cross section of Indochina-Bien DongSunda.

Wherever the thermal anomaly developed, in which BD seafloor spreading developed, that mean, the thermal anomaly stopped activity, BD seafloor spreading also immediately stopped.

b. The second energy resource created the wrench of spreading in SW part due to the stress from extrusion forward SE orientation and wrench in right of Indochinese block from 26 M.a until now (fig. 10). In recent time Indochinese Block drifted to SE ward with velocity $4.03 \mathrm{~cm} /$ year. 


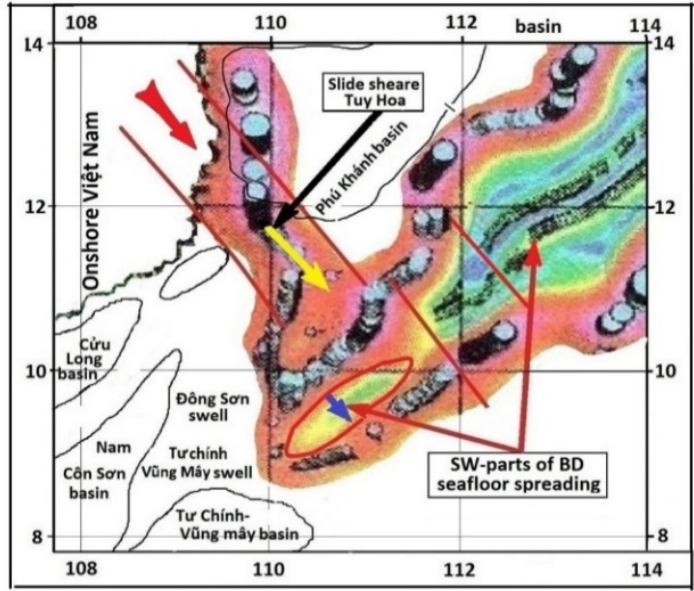

Figure 10: The Tuy Hoa slide shear extruded forward SE, moved to SW part of seafloor spreading into SE.

That mean, from 26 M.a the thermal anomaly was pushed up this stress and gradually changed it orientation and developed into SW, which created the condition of change of Spreading orientation in SW part and formed Borneo- Palawan subduction zone.( 26 - 16 M.a). But at the time of 16 M.a, the thermal anomaly decreased active intensity and slowly diet out to create the condition of stop for Bien Dong seafloor spreading. The crust was not enough of force to push forward SE, which conduced stop of activity of BorneoPalawan subduction at the time of 16 M.a.

Due to Bien Dong seafloor Spreading drew and carried forward SE, it is occurred the formation of some structures such as: Nam Con Sơn , Tư chinh -Vung Mây, group of basins Truong Sa, Sarawak and Palawan basins.

c. The Tuy Hoa slide sheared zone influenced on the SE movement of SW end part of Bien Dong Seafloor spreading toward SE (figures $04 \&$ 06).

\section{THE INFLUENCE OF SPREADING PROCESSES.}

Due to appearance of the thermal anomaly from mantle thermal plume produced the erosion of continental crust and formation of Bien Dong seafloor spreading with appearance of new oceanic crust.

Every rising basalt magmatic fluid and after that cooled and shrinked, conduced the formation a lot of fault systems, especially the deep faults in margins of Bien Dong Sea, which are the preconditions to form grabens, semigrabens and lead to form the sedimentary basins (Fig.11).

In general, the faults have the direction of slope toward the spreading axis, especially in Central part of seafloor spreading the faults oriented into Spreading (axis).

This condition created the formation and development of: Manila subduction zone (29 M.a), (Jolivet 1989), Borneo- Palawan subduction zone (26 M.a until 16 M.a) (Rangin 1990 and Proutau 1992).

The formation of sedimentary basins in margins, in which were accumulated the organic matter and generation of oil and gas when existed the favorable condition. For examples: In Northern margin existed Tainan basin (in SW Taiwan), River pearls, Beibuwan, South Hai Nam basin, In Eastern margin - Manila basin, In Southern margin - Palawan, Sarawak, Trương Sa basin group, In Western margin - Song Hong, Phu Khanh, Cuu Long, South Con Son, Tu Ching -Vung May basins. In those sedimentary basins the sediment formations have been discovered such as: Late Eocene, Oligocene, Miocene, Pliocene and Quaternary, from which very largely developed the sediment formations of Oligocene and Early Miocene.

Only in Northern margin are existed the sediments of Late Creta, Paleocene and Early Eocene, (Beibuwan, River Pearls).

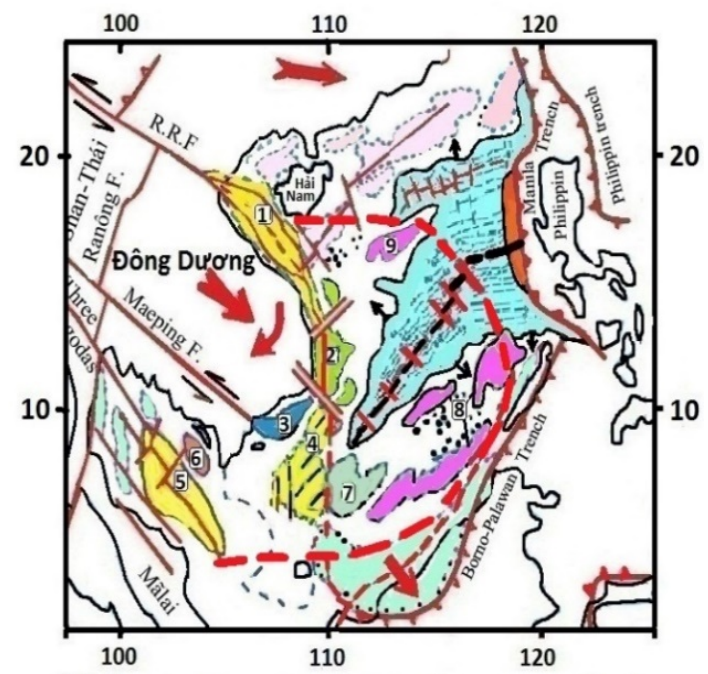

Figure 11: The area effected by stress of Indochinese block.

\section{Trang B6}




\section{Conclusions}

The mantle thermal plume acted from 36 M.a until 14 M.a and stopped. In this period it produced the formation of Bien Dong seafloor spreading.

The magmatic fluid uplifted along seafloor spreading in this area with 12 times and remained 12 magnetic anomalies. In general tendency, these anomalies gradually extended in two directions. The young anomalies were raised in Central zone and pushed up the old magnetic anomalies forward margins. This process formed the new oceanic crust in Central part of Bien Dong Sea.

The change of Spreading axis toward SW and developed into this direction occurred due to the extrusion of Indochinese block toward SE and wrenched in right in period of 26 M.a until now. This stress created the condition to form and develop
Seafloor Spreading axis into SW, which conducted the formation of Borneo- Palawan subduction zone (26- 16 M.a).

When the thermal plume decreased active intensity at the time of 16 M.a the spreading also stoped and stop of produced Borneo- Palawan subduction zone.

The above activities produced and developed a lot of fault systems with orientation NE- SW, E-W, Meridian, at the same time, to form a lot of sedimentary basins along the deep faults in margins.

Bien Dong Sea is degeneration continental crust and is erosion, Seafloor spreading with the extrusive basalt magma fluid in Central areas, with the new oceanic crust in this region. It is belong to transitional crust of suboceanic crust. That mean, it is. not become the effect oceanic crust.

\section{Tách giãn đáy Biển Đông và ảnh hưởng của nó đến quá trình hình thành \& phát triển của bể trầm tích}

- Nguyễn Mạnh Hùng

- Hoàng Đình Tiến

Trường Đại học Bách Khoa, ĐHQG-HCM

TÓM TÁT:

Bài báo phản ánh đặc điểm trục tách giãn đáy Biển Đông bao gồm 2 phần: phần phía Đông rộng lớn luôn phát triển theo hướng Đông - Tây (tách giãn hướng Bắc - Nam), phần Tây - Nam đổi dần hướng sang Đông Bắc -Tây Nam (Tách giãn hướng Tây Bắc-Đông Nam).

Động lực chủ yếu gây nên tách giãn và biến dạng như vậy là do hai nguồn lực chính đó là: Do xuất hiện dị thường nhiệt từ chùm nấm nhiệt manti cách đây 36 tr.n. đến 14 tr.n. Dị thường nhiệt ở phần Đông vẫn tiếp tục theo chiều hướng này. Còn ở phần Tây-Nam thay đổi hướng tách giãn cách đây 26 tr.n. từ Đông -Tây sang Đông bắc - Tây
Nam và phát triển dần theo hướng này. Cách đây 14 tr.n cả hai hướng dị thường này đều ngưng nghỉ, bắt đầu lạnh nguội và co ngót. Sự suất hiện dị thường nhiệt này dẫn đến vát mỏng và nứt tách vỏ lục địa ở trung tâm biển Đông, đồng thới hình thành vỏ đại dương mới (từ dị thường 13 vào 5a). Sụ̂ biến đổi hướng ở phần Tây - Nam của dị thường nhiệt là do sự thúc trồi xuống Đông Nam và xoay theo chiều kim đồng hồ của khối Đông Dương. Sự dâng trồi và biến đổi của dị thường nhiệt (magma bazalt) tạo thuận lợi cho sụ hình thành, phát triển và biến đổi của trục tách giãn đáy Biển Đông. Các hoạt động và hoạt hóa nêu trên 
tạo thuận lợi cho sự hình thành và phát triển hàng loạt hệ thống đứt gãy sâu hướng Đông -Tây ở phần phía Đông, hướng Đông Bắc - Tây Nam ỏ phần còn lại, đồng thời cũng hình thành và phát triển các bể trầm tích ven rìa Biển Đông dọc theo hệ thống đứt gãy sâu chính.

Từ khóa: Tách giãn đáy biển Đông, dị thường nhiệt, điều kiện thuận lợi.

\section{TÀI LIỆU THAM KHẢO}

[1]. Dietri Paoletti. Sedimentary basins of South East Asia. Report. Vũng Tàu 9/1979.

[2]. Taylor B. and Hays D.E. Origin and history of the South China Sea basins. In tectonic and geologic Evolution of the South East Asian Sea on island America Geophysics Union. Monograph series 17.

[3]. Khain V E. Tectonics of continents and oceans. Publishing. Scientific Mir. Moscow. 2001.

[4]. Briais. A et al. Update interpretation of magnetic anomalies and Seafloor spreading stages in the South China Sea. Implication for the Tertiary Tectonics of SouthEast Asia, J. Geophus. Res.

[5]. Hoang Dinh Tien. Some ideas about Bien Dong seafloor Spreading. Journal "PetroViet Nam" N 7/ 2009

[6]. Hoang Dinh Tien. Tectonic evolution and dynamic of Indochinese block SE Asia. Journal "PetroViet Nam" N 7/ 2010.

[7]. Hoang Dinh Tien. The main characteristics about tectonic - dynamic of sedimentary basins in Viet
Nam continental shelf and Bien Dong Sea due to influence of tectonic in SE Asia. Journal "PetroViet Nam" N 4/ 2011.

[8]. Hoang Dinh Tien. South Con Son basin in aspect of dynamic. Journal “PetroViet Nam” N 8/ 2012.

[9]. Hoang Dinh Tien. Petroleum geology, exploration methods and monitoring of field. Publishing: National University. HCM City (2006, second reprint 2012).

[10].Cao Dinh Trieu et al. Recent Geodinamics of VietNam territory. Publishing: Natural and technological Sciences, 2013.

[11].Trần Tuân Dung. Tectonic structure characteristics in deep water area of Viet Nam based on complex magnetic and gravity data interpretation. In Science of technology conference proceeding. Publishing: Science and Technology. III - 2013. Page 55 - 66

\section{Trang 138}

